\title{
ISLAM DAN KESETARAAN PEREMPUAN DALAM PENDIDIKAN
}

\author{
Ahmad Zumaro \\ Institut Agama Islam Negeri (IAIN) Metro \\ JL. Ki Hajar Dewantara No.15A, Iringmulyo, Metro Timur, Kota Metro, \\ Lampung \\ Email: ahmadzumaro@gmail.com
}

\begin{tabular}{|c|c|c|}
\hline Diterima: & Revisi: & Disetujui: \\
23 Agustus 2018 & 08 Oktober 2018 & 20 November 2018 \\
\hline
\end{tabular}

\begin{abstract}
Education is a human right for every individual and must be given without distinguish of sex. Therefore, education must be reached everyone without distinguish of sexs. But in practice, there are still among the moslems bound the women to get education. This is due to failure in understanding of women obligation to study. The mistaken in understanding text in the Al-Quran or hadith will cause errors in its application and can cause do harm to women.
\end{abstract}

Keyword: education, equality, and women

\begin{abstract}
Abstrak
Pendidikan merupakan hak asasi bagi tiap individu. Oleh sebab itu, pendidikan harus menjangkau setiap orang tanpa membedakan jenis kelamin. Namun pada prakteknya, masih ada di antara umat Islam yang masih memasung hak pendidikan pada wanita. Hal ini disebabkan pemahaman yang salah terhadap dalil yang berkenaan dengan kewajiban bagi wanita untuk menuntut ilmu. Kekeliruan dalam memahami sebuah teks baik yang terdapat dalam Al-Quran maupun hadis akan menimbulkan kesalahan dalam penerapannya, dan dapat menimbulkan kerugian khususnya pada wanita.
\end{abstract}

Kata Kunci: pendidikan, keseteraan dan wanita 


\section{A. Pendahuluan}

Pendidikan merupakan suatu kebutuhan yang sangat fundamental bagi setiap individu. tidak akan tercipta suatu peradaban pada suatu bangsa apabila pendidikan masyarakatnya terbelakang. Pendidikan merupakan upaya untuk mengembangkan potensi yang ada dalam diri tiap individu agar tumbuh dan berkembang secara maksimal. Tak ada solusi yang paling tepat untuk menghilangkan kebodohan dan keterbelakangan kecuali dengan pendidikan. namun, pendidikan yang begitu penting, kadang belum dapat dirasakan sepenuhnya oleh tiap individu.

Diskriminasi ini kerap terjadi terutama menimpa kaum Hawa. Padahal perbedaan jenis kelamin laki-laki dan perempuan bukanlah alasan untuk mendeskriditkan salah satunya. Persoalaan marginalisasi kaum Hawa justru timbul disebabkan atau timbul dari budaya dan ajaran agama akibat kesalahan dalam penafsiran mengenai keberadaan wanita dalam ajaran Islam yang seolah-olah melegitimasi kejadian ini.

Kesalahan persepsi disebabkan interpretasi yang keliru terhadap sosok wanita dalam ajaran Islam. Jane I Smith dalam penelitiannya terkait dengan peran serta status wanita Islam menemukan kenyataan pada banyak masyarakat muslim berasumsi bahwa wanita diciptakan untuk menjadi istri yang baik dan menjadi teman bagi ibunya. Bahkan hal ini sudah menjadi dogma bahwa wanita desa yang bodoh lebih baik untuk suatu bangsa daripada seribu ahli hukum dan pengacara wanita. ${ }^{1}$

Hal ini menegaskan bahwa wanita memang selalu diposisikan sebagai makhluk yang dicitrakan untuk berdiam di rumah dan tidak boleh belajar menuntut ilmu. Wanita akan lebih terhormat apabila dirinya berada di rumah mengurus pekerjaan rumah meskipun bodoh, daripada wanita yang banyak memiliki pengetahuan. Hal ini juga tentu akan mempengaruhi pandangan anak terhadap wanita sehingga

1 Jawad Haiffa A, The Rights Of Women In Islam: An Autentich Approach, (New York: ST Martin's Press, inc, 1998), h. 25 
menjadi suatu kebiasaan turun temurun, bahwa wanita tidak perlu belajar atau menuntut ilmu.

Terbelenggu dan dibelenggunya wanita seolah-olah sudah menjadi hal yang lumrah. Keadaan ini menunjukkan bias gender serta ketimpangan dan akan menimbulkan kerugian tidak hanya pada wanita tetapi juga akan mempengaruhi keadaan suatu masyarakat atau bangsa. Hal ini menjadi masalah keagamaan. Dikatakan masalah agama sebab praktek seperti ini bertentangan dengan prinsip ajaran Islam yang sangat menjunjung tinggi kebebasan dan keadilan serta persamaan dalam bidang pendidikan dan Islam sangat mengecam kebodohan. Tulisan ini secara khusus akan membahas mengenai kesetaraan perempuan dalam pendidikan secara normatif dengan menghadirkan teks baik al-Quran maupun hadis.

\section{B. Wanita dan Belenggu Pendidikan}

Secara historis telah terjadi dominasi laki-laki dalam semua masyarakat di sepanjang zaman dan selama itu juga perempuan mengalami perlakuan yang tidak adil dalam berbagai aspek kehidupan. Sejarah mencatat bagaimana wanita dalam prakteknya selalu dijadikan makhluk subordinasi atau second sex. Wanita tidak mendapatkan tempat yang layak dan mulia. Pada masa peradaban Romawi, Yunani, dalam hukum Hamurabi, India, Yahudi dan Kristen, wanita sangat dihina dan dilaknat karena dianggap telah menjerumuskan Adam. Wanita dipandang kotor, bahkan disamakan dengan hewan piaraan. ${ }^{2}$

Pada masa jahiliah, perlakuan terhadap wanita tak ubahnya seperta perlakuan wanita pada umumnya saat itu. wanita yang mati ditinggal suaminya dan meninggalkan anak laki-laki, maka anak yang paling besar berhak atas istri (ibunya). Anak tersebut dapat mewarisi istri bapaknya sebagaimana ia mewarisi harta warisan. Jika ia menghendaki, ia bisa menikahinya tanpa mahar atau menikahkan 2000) h. 269

2 Wahbah Zuhaili, Kebebasan Dalam Islam, (Jakarta: Pustaka Al-Kautsar, 
dengan pria lain dan mengambil maharnya atau melarang untuk menikah. ${ }^{3}$

Pada masa itu juga memiliki anak perempuan merupakan sesuatu yang hina atau aib yang memalukan terutama bagi para petinggi kabilah. Untuk menghilangkan rasa malu dan aib anak perempuan yang baru lahir di bunuh dengan cara di kubur hiduphidup. Kalaupun mereka tidak di bunuh mereka hanya akan menjadi pemuas nafsu para lelaki. Hal ini bertolak belakang dengan kelahiran seorang bayi laki-laki. Mereka disanjung dan sangat dihormati sebab akan menjadi calon pemimpin dalam keluarga mereka. ${ }^{4}$ Sementara itu, menurut Abduh seperti yang dikutip oleh Su'ad Ibrahim Shalih, ada beberapa sebab mengapa anak laki-laki diistimewakan pada masa itu, yaitu: pertama, harapan akan bantuan dan jaminan keselamatan dari anak laki-laki ketika orang tua sedang lemah dan diperlukan; kedua, dalam tradisi masyarakat arab yang patriarkhi anak laki-laki menyambungkan silsilah atau garis keturunan; ketiga, harapan akan mendapat kemuliaan dari kaum laki-laki, seperti memimpin perang; keempat, tradisi lama yang sudah mendarah daging, apabila anak perempuan tidak mampu menjaga kehormatannya maka keluarga akan mendapat aib dan dengan anggapan seperti itu, lalu berkuranglah rasa cinta mereka terhadap anak perempuan; dan kelima, walaupun anak perempuan sudah didik dan dibesarkan, anak perempuan akan keluar dari rumahnya ikut dengan suaminya, seolaholah apa yang selama ini diberikan kepadanya berupa nafkah sama halnya dengan memberi orang asing. ${ }^{5}$

Hingga kini wanita masih merasakkan dampak dari budaya serta dogma ajaran agama yang dianggap benar. Diskriminasi terhadap wanita ini juga berimbas kepada keterbatasan wanita untuk mendapatkan akses pendidikan. Dari uraian mengenai wanita dalam lintas sejarah berbagai bangsa di dunia dan masa jahiliah atau pra

${ }^{3}$ QS. An-Nisa [4]:19

${ }^{4}$ QS. At-Takwir [81]:8-9

${ }^{5}$ Su'ad Ibrahim Shalih, Fiqh Ibadah Wanita, Ter. Nadirsah Hawari, (Jakarta: Amzah, 2001), h. 21 
Islam, terlihat jelas bahwa wanita memang secara sistemik dibelenggu dalam bungkus agama.

\section{Islam dan Ruang Pendidikan Yang Terbuka}

Islam datang sebagai agama rahmat agama kasih sayang bagi seluruh alam. Tradisi maupun ajaran agama yang bertentangan dengan nilai kemanusian bahkan kemakhlukan dihilangkan secara bertahap. Islam menghapus tradisi jahiliah yang berlaku saat itu yang dinilai sangat jauh dari sifat kemanusian. Ajaran Islam melarang wanita dijadikan sebagai objek warisan. ${ }^{6}$ Begitu juga dengan tradisi pembunuhan bayi perempuan, Islam mengharamkan perbuatan yang tidak berkeprimanusian tersebut. ${ }^{7}$ Begitu juga dengan masalah pendidikan, Rasulullah SAW tidak pernah melarang wanita keluar rumah untuk menuntut ilmu. Bahkan dalam sejarah tercatat Nabi memberikan hari tertentu untuk mengajar bagi kaum wanita.

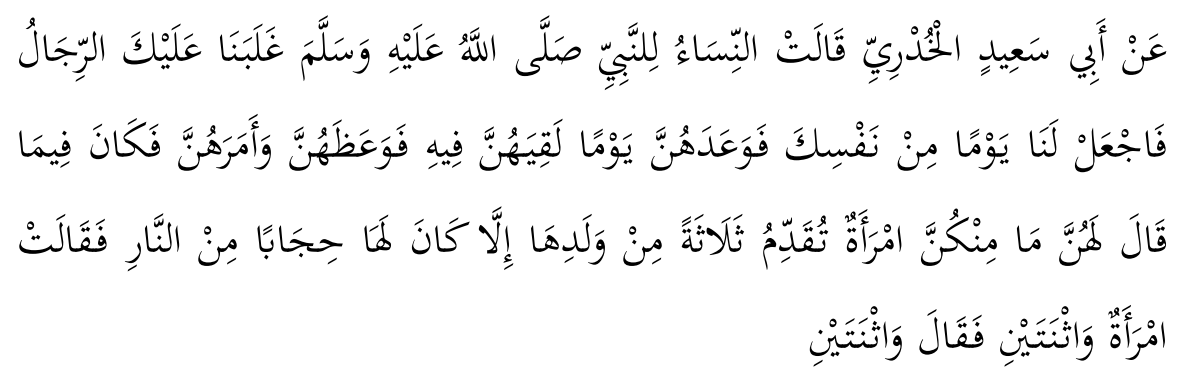

${ }^{6}$ Wahai orang-orang yang beriman, tidak halal bagi kamu mewarisi wanita dengan jalan paksa dan janganlah kamu menyusahkan mereka karena hendak mengambil kembali sebagian dari apa yang telah kamu berikan kepadanya, terkecuali jika mereka melakukan perbuatan keji yang nyata. Dan bergaullah dengan mereka (para isteri) secara ma'ruf (baik/patut). Kemudian bila kamu tidak menyukai mereka, (maka bersabarlah) karena mungkin kamu tidak menyukai sesuatu, padahal Allah menjadikan padanya kebaikan yang banyak (Q.S an-Nisaa':19)

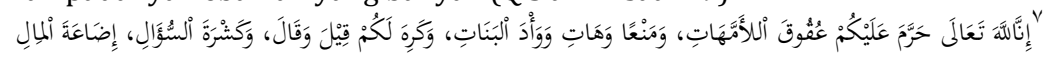

"Sesungguhnya Allah mengharamkan atas kamu, durhaka pada ibu dan menolak kewajiban, dan minta yang bukan haknya, dan membunuh anak hidup-hidup, dan Allah membenci padamu banyak bicara, dan banyak bertanya demikian pula memboroskan harta (menghamburkan kekayaan)" Muh\{ammad Ibn Ismāil AlBukhāri, Sahịh Al-Bukhārì, "Kitab Fil Istiqrad Wa Ada' Ad-Duyun: Ma Yanha 'An Idhoatil Mal, (Beirūt: Dār-Alfrkr, t.t), h. 575 
Artinya:

Dari Abu Sa'id Al Khudri; kaum wanita berkata kepada Nabi SAW: "kaum lelaki telah mengalahkan kami untuk bertemu dengan engkau, maka berilah kami kesempatan waktu untuk bermajelis dengan diri tuan" Maka Nabi SAW berjanji kepada mereka untuk bertemu mereka, lalu Nabi SAW memberi pelajaran dan memerintahkan kepada mereka, diantara yang disampaikannya adalah: "Tidak seorangpun dari kalian yang didahului oleh tiga orang dari anaknya kecuali akan menjadi tabir bagi dirinya dari neraka". Berkata seseorang: "bagaimana kalau dua orang?" Nabi SAW menjawab: "Juga dua".8

Bersedianya Rasulullah menyediakan waktu dalam memberi pelajaran bagi kaum wanita adalah petunjuk bahwa Rasulullah SAW menyadari pentingnya pendidikan. Pendidikan merupakan sarana manusia dapat untuk dapat mengembangkan serta memaksimalkan potensinya masing-masing. Hal ini telah disabdakan beliau dalam hadisnya.

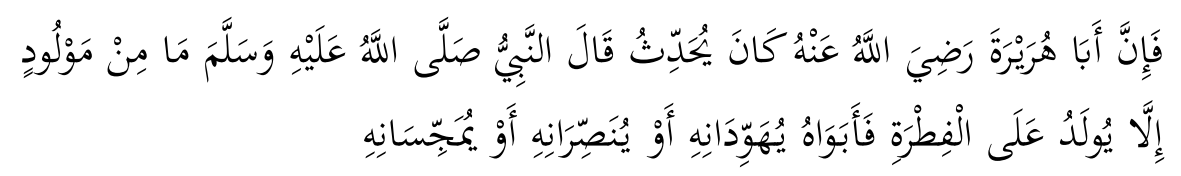

Artinya:

Tiap orang dilahirkan membawa fitrah; kedua orang tuanyalah yang menjadikannya Yahudi, Nasrani, Majusi. ${ }^{9}$

Manusia adalah makhluk psiko-fisik yaitu makhluk yang memiliki dua unsur jiwa dan tubuh. Dalam unsur ini Allah memberikan seperangkat kemampuan dasar yang memiliki kecenderungan, dalam psikologi disebut potensialitas atau disposisi yang menurut pandangan Islam dinamakan "Fitrah". Ada beberapa pengertian mengenai fitrah. Tiap anak yang dilahirkan dalam keadaan

${ }^{8}$ Al-Bukhāri, Șahịh Al-Bukhārì “Kitab Al-Ilmu:Bab Hal Yaj’alu Li Nisa' Yaum Haddatin Fil Ilm, h. 46

${ }^{9}$ Al-Bukhārì, Șahịh Al-Bukhārì, "Kitab Tafsir:Bab La Tabdila li Khalqillah, h. 1204 
fitrah, artinya anak berpotensi tauhid dan berpotensi untuk berbuat baik. Tidak ada anak yang memiliki bakat jelek, apabila diberi kesempatan dan diberi peluang untuk mengembangkan potensinya dengan baik, maka ia akan menjadi baik.

Manusia dilahirkan dengan membawa fitrah (potensi) yang berbeda. Fitrah inilah yang harus digali dan dimaksimalkan, agar setiap manusia memiliki kemampuan serta keahlian di bidangnya masing-masing.

Adapun faktor yang mempengaruhi perkembangan potensi diri atau fitrah manusia adalah lingkungan. Setiap individu akan dipengaruhi oleh lingkungan keluarga, lingkungan sekolah dan lingkungan masyarakat. Ketiga lingkungan ini biasa disebut dengan tripusat pendidikan. Lingkungan memiliki peran signifikan memberikan andil dalam serta memaksimalkan kemampuan manusia. Dari ketiga lingkungan tersebut yang paling mempengaruhi perkembangan anak adalah lingkungan keluarga. Keluarga merupakan lingkungan di mana setiap anak memperoleh pendidikan awal. Keluarga yang terdiri dari ayah, ibu dan anak. Orang tua bertanggung jawab merawat, melindungi serta mendidik anak agar tumbuh kembangnya baik. Namun karena keterbatasan orang tua, tugas mendidik tidak dapat dilaksanakan orang tua secara maksimal. Untuk memaksimalkan bakat serta kemampuan anak baik sisi keilmuan dan keterampilan, dalam konteks saat ini orang tua dituntut untuk memasukkan anaknya pada lembaga pendidikan formal atau sekolah.

Lembaga pendidikan formal saat ini merupakan wadah untuk mengembangkan potensi serta kemampuan tiap anak. Oleh sebab itu, Islam mewajibkan setiap individu untuk menuntut ilmu. Dalam hadisnya rasulullah saw besabda; 


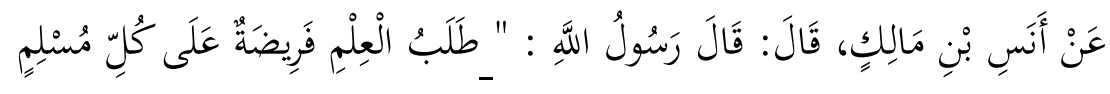

Artinya:

Dari Anas bin Malik, Rasulullah SAW bersabda, "menuntut ilmu kewajiban bagi tiap muslim."10

Hadis ini sering dimaknai secara tekstual sehingga menghasilkan kesalahan makna. Secara eksplisit teks hadis ini khusus ditujukan kepada kaum pria, karena hanya tertulis kalimat muslim yang secara harfiah dimaknai sebagai laki-laki. Dengan kata lain, bahwa kewajiban menuntut ilmu hanya diperuntukkan bagi kaum lelaki, sedangkan wanita sama sekali tidak ada kewajiban untuk menjalankannya. Dengan kata lain, wanita dalam Islam tidak diharuskan untuk menuntut ilmu. Padahal perintah taklif yang ditujukan kepada laki-laki dalam bentuk tunggal (muslim) atau mufrad muzakkar dan jamak atau plural muzakkar (muslimin) maknanya mencakup seluruh jenis kelamin, wanita dan pria. Dengan demikian menuntut ilmu merupakan suatu kewajiban bagi tiap muslim baik pria dan wanita. ${ }^{11}$

Apabila perintah menuntut ilmu merupakan kewajiban yang berlaku baik bagi Muslim laki-laki maupun perempuan, maka artinya mereka memiliki hak yang sama untuk menuntut ilmu. Dengan kata lain, tidak benar apabila ada ajaran Islam yang membatasi akses pendidikan bagi perempuan, karena hak untuk mendapatkan ilmu merupakan hak dasar yang langsung dijamin oleh Allah dan RasulNya. Bahkan pada masanya rasulullah mendirikan madrasah pertama yang diberi nama Darul Arqom. ${ }^{12}$

10 Abu Ya'la Ahmad Bin Ali Bin Al-Mutsana, Musnad Abu Ya'la Al-Maushili, (tt.p: Darul Makmun, 1989), h. 756

11 Bahkan ada yang memaksakan dengan menambah redaksi muslimatun, agar kewajiban menuntut ilmu secara tekstual termaktub dalam redaksi hadis, sehingga dapat dimaknai bahwa wanita juga mempunyai kewajiban menuntut ilmu.

12 Dinamakan Darul Arqom karena memang tempat ini merupakan kediaman atau rumah Arqom. Dipilihnya tempat ini karena letaknya di gang-gang sempit di antara pemukiman-pemukiman lain di Makkah sehingga tempat tidak 
Di tempat ini para sahabat diajarkan membaca dan menghafal Al-Quran secara benar dan hukum Islam di bawah bimbingan Nabi SAW. Islam juga tidak melarang wanita keluar rumah untuk menuntut ilmu. Dalam hadisnya Rasulullah SAW tidak melarang wanita keluar untuk menjalankan kewajibannya sebagai muslim apabila untuk keperluan yang amat penting.

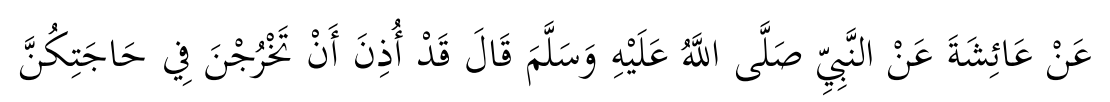
Artinya:

Dari Aisyah dari Nabi SAW berkata, "Rasulullah SAW mengizinkan perempuan keluar rumah untuk memenuhi kebutuhan atau hajatnya. ${ }^{13}$

Pendidikan merupakan kebutuhan yang tidak boleh diabaikan bagi tiap muslim, oleh sebab itu Rasulullah tidak melarang wanita keluar rumah untuk memenuhi hajat atau kebutuhannya menuntut ilmu. Menurut ibn Jauzi wanita adalah seorang mukallaf sebagaimana pria. Oleh karenanya, dia wajib menuntut ilmu agar segala apa yang dilakukannya dari syariat Islam berdasarkan keyakinan. ${ }^{14}$

Pendapat Ibn Jauzi ini dipertegas lagi dalam Al-Quran yang menyatakan bahwa larangan bagi manusia untuk taklid atau mengikuti sesuatu yang tidak diketahui. Islam memerintahkan umatnya untuk selalu berfikir menggunakan akalnya. Akal merupakan anugerah terbesar yang dimiliki manusia. Oleh sebab itu, Islam memerintahkan manusia untuk berfikir mengenai ayat atau tandatanda baik makrokosmos maupun mikrokosmos agar darinya manusia mendapat pengetahuan. Melalui pengetahuan ini keyakinan umat Islam semakin bertambah terhadap adanya dan kebesaran Allah

dicurigai oleh kaum kafir Quraish. Pada masa itu ada satu orang wanita yang telah masuk islam yaitu Sumayyah binti Khabath ibunda Ammar bin Yasir.

13 Al-Bukhārì, Șahịh Al-Bukhārì, "Kitab al-Wudhu:Bab Khuruj An-Nisa Fil Baraz, h. 57

${ }^{14}$ Ibn Al-Jauzi, Kitab Ahkam An-Nisa, (Mesir:Maktabah Ibn Taimiyah, 1997), 38 
SWT.15 Pengetahuan dan keyakinan mengenai keberadaan dan kebesaran Allah SWT dapat menjadikan manusia yang takut atau tunduk serta patuh kepada-Nya.

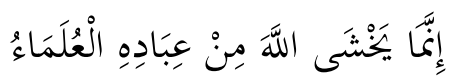

Artinya:

Sesungguhnya yang takut kepada Allah di antara hambahamba-Nya, hanyalah ulama."16

Ayat ini menerangkan hanya orang yang berilmu (ulama) yang takut (khasyah) kepada Allah. Penggunaan objek dalam ayat ini didahulukan yaitu lafzuljalalah atau kalimat Allah, sedangkan subjeknya (ulama) diakhirkan. Hal ini menunjukkan makna pengecualian atau pembatasan bahwa hanya ulama atau orang yang cerdas yang takut atau patuh terhadap perintah Allah. Makna takut di sini adalah takut berbuat dosa sehingga ia selalu berhati-hati dalam berbuat. Takut yang berlandaskan pengetahuan tentang hal-hal yang dilarang maupun perintah yang wajib dikerjakan dan konsekwensi yang diterima bagi yang melanggar serta mengerjakan perintah-Nya. Bagi orang yang berakal mereka akan selalu mawas diri, menghindari segala perbuatan yang melanggar perintah-Nya.

Dengan demikian yang disebut orang cerdas dalam Islam adalah orang yang memiliki pengetahuan yang dengan pengetahuannya itu menjadikannya patuh serta tunduk kepada Allah SWT. Dari ayat ini dapat dipahami bahwa orang yang takut kepada Allah adalah ulama. Penggunaan kata ulama tidak menunjukkan jenis

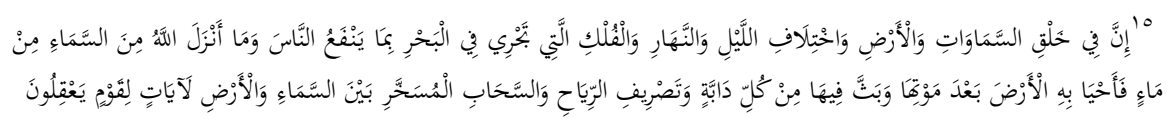
Artinya: Sesungguhnya dalam penciptaan langit dan bumi, silih bergantinya malam dan siang, bahtera yang berlayar di laut membawa apa yang berguna bagi manusia, dan apa yang Allah turunkan dari langit berupa air, lalu dengan air itu Dia hidupkan bumi sesudah mati (kering)-nya dan Dia sebarkan di bumi itu segala jenis hewan, dan pengisaran angin dan awan yang dikendalikan antara langit dan bumi; sungguh (terdapat) tanda-tanda (keesaan dan kebesaran Allah) bagi kaum yang memikirkan.

16 QS. Fathir [35]:28 
kelamin tertentu, oleh sebab itu, siapa saja yang takut kepada Allah dialah yang disebut ulama. Rasulullah dalam hadisnya memberikan keterangan tambahan mengenai ciri orang yang cerdas:

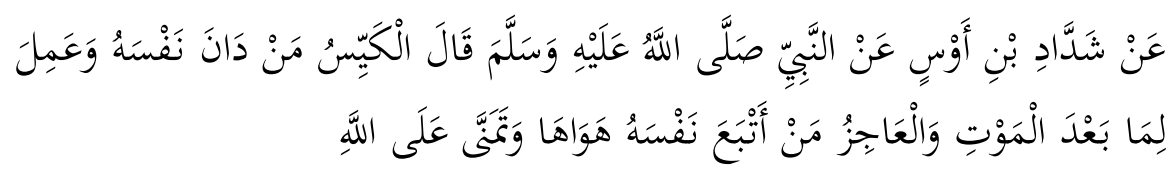

Artinya:

Dari Saddad ibnu Aus R.A. dari Nabi saw. Beliau bersabda: “Orang yang cerdas ialah orang yang mampu mengintrospeksi dirinya dan suka beramal untuk kehidupannya setelah mati. Sedangkan orang lemah ialah orang yang selalu mengikuti hawa nafsunya dan berharap kepada Allah dengan harapan kosong".17

Indikator cerdas dalam hadis ini adalah pertama, orang yang selalu melakukan introspeksi diri, yaitu orang yang selalu mengoreksi dirinya sendiri dengan melihat kekurangan dirinya kemudian diajukan acuan untuk merubah menjadi pribadi yang lebih baik dan kedua, ialah mereka yang menjadikan dunia sebagai ladang menuju akhirat. Manusia cerdas adalah mereka yang patuh akan perintah Allah SWT dan menjauhi larangan-Nya dan segala perbuatannya hanya ditujukkan kepada-Nya. Dalam redaksi hadis ini pun tidak menyinggung jenis kelamin. Dengan demikian, orang cerdas atau ulama dalam Islam ialah siapa saja yang menjadikan dirinya sebagai cermin atau selalu introspeksi untuk perbaikan diri serta mengorientasikan hidupnya hanya kepada akhirat atau Allah. Dari ayat maupun hadis ini dapat dipahami bahwa untuk menjadi ulama yang takut dan tunduk kepada Allah tidak menuntut adanya jenis kelamin tertentu.

Kesamaan hak dalam menuntut ilmu bagi pria dan wanita dalam Islam bukan berarti adanya kewajiban atau tuntutan bagi

${ }^{17}$ Abu Abdullah Muhammad Bin Yazīd Ibn Mājah Al-Qozwaini:Sunan Ibn Majah, Kitab Az-Zuhdu: Kitb Zikrul Maut Wal Isti'dad Lah (Riyad:Baitul Afkār AdDawliyah, t.t), h. 459 
wanita untuk bekerja di luar rumah atau menjadi wanita karier. Sebab, pendidikan bagi wanita dalam konteks keluarga memiliki arti penting. Wanita akan menjadi seorang ibu apabila ia telah menikah dan memiliki anak. Ibu merupakan sekolah atau pendidik pertama bagi anak-anaknya. Perempuan atau ibu yang berpendidikan memiliki andil besar dalam pembentukkan generasi berkualitas. Ibu yang berpendidikan akan lebih baik mendidik anaknya dibanding wanita yang tidak mengenyam pendidikan. Ibu yang berpendidikan akan melahirkan generasi terbaik, begitu juga sebaliknya kurangnya pendidikan ibu berpotensi menurunkan generasi berkualitas pada generasi dan kelompok masyarakat tertentu. Dengan demikian, wanita dituntut harus berpendidikan tinggi meskipun nantinya ia hanya menjadi ibu rumah tangga atau tidak berkarir dalam ranah publik.

Pepatah Arab mengatakan bahwa, ibu merupakan pendidik atau sekolah pertama bagi anak-anaknya.

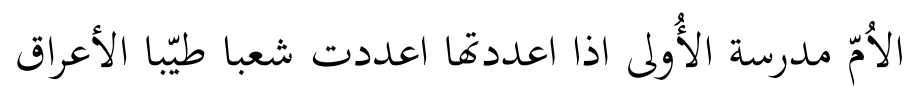

Artinya:

Ibu adalah sekolah utama, bila engkau mempersiapkanya maka engkau telah mempersiapkan generasi yang yang baik budi pekertinya.

Peran ibu dalam pembentukan watak, karakter, kepribadian serta kecerdasan anak sangat menentukan. Ibu yang terdidik akan mampu melayani anaknya dengan pelayanan yang sebaik-baiknya sedari usia dini sampai anak-anaknya mandiri dan mampu memberi kontribusi positif terhadap masyarakat dan bangsa. Ibu merupakan gudang ilmu, wadah peradaban. Peran wanita yang sangat penting ini, menuntut wanita untuk membekali diri dengan berbagai pengetahuan serta keahlian. Seorang ibu tidak boleh diam, dia harus terus bergerak meningkatkan kualitas diri agar tercipta generasi penerus yang berkualitas. Disinilah pentingnya kesamaan akses pendidikan bagi wanita. 


\section{Kesimpulan}

Islam memberikan jaminan bagi perempuan hak yang sama dengan laki-laki dalam memperoleh pendidikan. Keberpihakan Islam terhadap perempuan pada hakikatnya merupakan bentuk perlawan dan sekaligus upaya advokasi Rasulullah saw terhadap perempuanperempuan di masa jahiliyah yang sangat sulit mendapatkan kebebasan dan kesamaan dalam bidang pendidikan. Kesetaraan akses pendidikan setelah masa Rasulullah menjadi rigid disebabkan oleh pemahaman dan penafsiran keliru yang bersifat tendensius terhadap kaum wanita. Pemasungan pendidikan terhadap kaum wanita merupakan hal yang berlawanan dengan ajaran agama Islam yang menuntut umatnya, baik laki-laki maupun wanita untuk selalu menjadi pribadi yang cerdas dan kritis.[]

\section{Daftar Pustaka}

Ahmad Bin Ali Bin Al-Mutsana, Abu Ya'la, Musnad Abu Ya'la AlMaushili, tt.p: Darul Makmun, 1989.

Al-Bukhārì, Mụ̣ammad Ibn Ismāil, Șaḥị̣ Al-Bukhārīi, Beirūt:Dār-Alfrkr, t.t

Al-Jauzi, Ibn, Kitab Ahkam An-Nisa, Mesir: Maktabah Ibn Taimiyah, 1997.

Haiffa A, Jawad, The Rights Of Women In Islam:An Autentich Approach, New York: ST Martin's Press, Inc, 1998.

Muḥammad Bin Yazīd Ibn Mājah Al-Qozwaini, Abu Abdullah, Sunan Ibn Majah, Riyaḍ: Baitul Afkār Ad-Dawliyah, t.t

Shalih, Su'ad Ibrahim, Fiqh Ibadah Wanita, Ter. Nadirsah Hawari, Jakarta: Amzah, 2001

Wahbah Zuhaili, Kebebasan Dalam Islam, Jakarta: Pustaka Al-Kautsar, 2000. 